\title{
Studi Perbandingan Analisis Respon Spektra dan Time History untuk Desain Gedung
}

\author{
Dilla Ayu Laila Nurul Bayyinah dan Faimun \\ Jurusan Teknik Sipil, Fakultas Teknik Sipil dan Perencanaan, Institut Teknologi Sepuluh Nopember (ITS) \\ Jl. Arief Rahman Hakim, Surabaya 60111 Indonesia \\ e-mail: faimun@ce.its.ac.id
}

\begin{abstract}
Abstrak-Untuk memperhitungkan pengaruh gaya lateral akibat gempa terhadap struktur bangunan biasanya dihitung dengan 2 (dua) pendekatan, yaitu analisis statik (statik ekivalen), analisis dinamik (respon spektra dan time history). Pengaruh gempa rencana pada struktur bertingkat banyak dengan ketinggian lebih dari 10 tingkat atau $40 \mathrm{~m}$ harus ditinjau sebagai pengaruh beban dinamik dan analisisnya harus didasarkan pada analisis dinamis (SNI 1726 2012).

Saat ini banyak studi yang membahas tentang analisis linier spektra. Pada penelitian ini, akan dibandingkan analisis linier respon spektra dan linier time history. Gedung didesain dengan analisis respon spektra kemudian desain tersebut dievaluasi dengan analisis linier time history. Data gempa untuk time history menggunakan 3 (tiga) rekaman gempa yaitu gempa Kobe (Jepang, 1995), Imperial Valley (California, 1979) dan Tabas (Iran, 1978). Dari ketiga data gempa tersebut diambil yang nilai terbesar.

Hasil studi menunjukkan adanya perbedaan antara kedua analisis tersebut. Nilai base shear respon spektra lebih besar dibandingkan analisis linier time history. Presentase penurunan nilai base shear dari 3 (tiga) gempa dengan analisis linier time history terhadap respon spektra yaitu sebesar 4,69 \% Kobe - $x$; $11,32 \%$ Kobe -y; 62,4 \% Imperial Valley - $x$; 83,046 \% Imperial Valley - y; 8,1 \% Tabas -x dan 12,1 \% Tabas - y. Hasil simpangan dengan respon spektra aman terhadap simpangan ijin, kemudian dievaluasi dengan analisis linier time history masih dalam kategori aman tapi pada simpangan arah - $x$, gempa imperial valley melebihi simpangan respon spektra dan arah y di beberapa lantai melebihi respon spektra. Data simpangan menunjukkan bahwa gempa imperial valley menyebabkan simpangan terbesar dari ketiga gempa yang ditinjau. Hasil desain dituangkan dalam gambar.
\end{abstract}

Kata Kunci-desain gedung, gempa dinamik, linier time history, respon spektra.

\section{PENDAHULUAN}

$\mathrm{G}$ EMPA bumi adalah suatu gerakan tiba-tiba yang terjadi dipermukaan bumi akibat adanya energi dalam bumi yang menciptakan gelombang kesegala arah. Gempa yang sampai di permukaan tanah dapat berpengaruh terhadap bangunan yang ada diatasnya, sehingga perlu diamankan. Untuk mengamankan bangunan tersebut, bangunan harus didesain sebagai bangunan tahan gempa yang direncanakan sesuai dengan peraturan gempa yang ada.

Untuk memperhitungkan pengaruh gaya lateral akibat gempa terhadap struktur bangunan biasanya dihitung dengan 2 (dua) pendekatan, yaitu analisis statik (statik ekivalen), analisis dinamik (respon spektra atau time history). Pengaruh gempa rencana pada struktur bertingkat banyak dengan ketinggian lebih dari 10 tingkat atau $40 \mathrm{~m}$ harus ditinjau sebagai pengaruh beban dinamik dan analisisnya harus didasarkan pada analisis dinamis (SNI 1726 2012), karena itu penulis mencoba membandingkan analisis gempa dinamik respon spektra dengan time history untuk mengetahui seberapa besar perbedaannya.

Penulis mencoba mendesain gedung dengan menggunakan analisis respon spektra kemudian hasil desain dibandingkan dengan menggunakan analisis linier time history. Pemodelan menggunakan bangunan yang diletakkan di kota Padang sebagai wilayah gempa tinggi. Studi ini sangat dibutuhkan karena dapat menentukan perbedaan dari kedua metoda analisis dan dapat mengetahui pertimbangan apa saja dalam menentukan analisis gempa.

\section{TINJAUAN PUSTAKA}

\section{Ground Motion}

Untuk menganalisis gempa dengan respon spektra dapat dilihat ketentuannya pada SNI 1726 - 2012 dengan data tanah Padang, sedangkan analisis linier time history, diperlukan rekaman gempa asli. Data gempa yang digunakan diambil dari situs PEER (Pasific Earthquake Engineering Research Center). Sedikitnya 3 (tiga) data gempa dan diambil yang terbesar [1].

Setiap pasang gerak tanah tersebut harus diskalakan sedemikian rupa sehingga pada rentang perioda dari $0,2 \mathrm{~T}$ hingga 1,5T, nilai rata-rata spektrum SRSS dari semua pasang komponen horizontal tidak boleh kurang dari nilai ordinat terkait pada spektrum respons yang telah ditentukan [1]. Salah satu gerak tanah (ground motion) yang diambil dari situs PEER dapat dilihat pada gambar 1

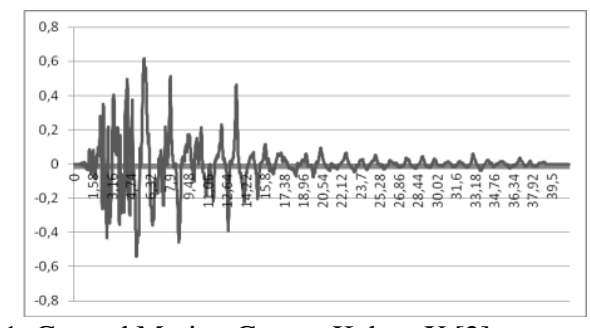

Gambar 1. Ground Motion Gempa Kobe - X [2] 
Faktor skala gempa didapatkan dengan rumus berikut:

$$
S F=\frac{\left(\sum_{i=1}^{n}\left(\overline{A_{i}} \times A_{i}\right)\right)}{\left(\sum_{i=1}^{n}\left(A_{i} \times A_{i}\right)\right)}
$$

Keterangan :

$\mathrm{A}_{\mathrm{i}}=$ Percepatan Ground Motion

$\overline{A_{i}}=$ Percepatan SNI 17262012

Tabel 1.

Data Ground Motion [4]

\begin{tabular}{rlrlr}
\hline No & Gempa & Thn & Stasiun & M \\
\hline 1 & Tabas, Iran & 1978 & Tabas & 7,4 \\
2 & Imperial Valley & 1979 & EC Meloland Overpass FF & 6,5 \\
3 & Imperial Valley & 1979 & El Centro Array \#7 & 6,5 \\
4 & Superstition Hills & 1987 & Parachute Test Site & 6,5 \\
5 & Loma Prieta & 1089 & LGPC & 6,9 \\
6 & Erxincan, Turkey & 1992 & Erzincan & 6,7 \\
7 & Northridge & 1994 & Jensen Filter Plant & 6,7 \\
8 & Northridge & 1994 & Newhall-W Pico Canyon & 6,7 \\
9 & Northridge & 1994 & Rinaldi Receiving Sta & 6,7 \\
10 & Northridge & 1994 & Sylmar-Converter Sta & 6,7 \\
11 & Northridge & 1994 & Sylmar-Converter Sta East & 6,7 \\
12 & Northridge & 1994 & Sylmar - Olive View Med & 6,7 \\
13 & Kobe, Japan & 1995 & Port Island & 6,9 \\
14 & Kobe, Japan & 1995 & Takatori & 6,9 \\
15 & Kocaeli, Turkey & 1999 & Yarimca & 7,4 \\
16 & Chi-Chi, Taiwan & 1999 & TCU052 & 7,6 \\
17 & Chi-Chi, Taiwan & 1999 & TCU065 & 7,6 \\
18 & Chi-Chi, Taiwan & 1999 & TCU068 & 7,6 \\
19 & Chi-Chi, Taiwan & 1999 & TCU084 & 7,6 \\
20 & Chi-Chi, Taiwan & 1999 & TCU102 & 7,6 \\
21 & Duzce, Turkey & 1999 & Duzce & 7 \\
\hline \hline & & & & \\
\hline
\end{tabular}

\section{METODOLOGI}

\section{A. Tahap Pengumpulan Data}

Pada gambar 2 dan 3 terlihat bahwa terdapat perbedaan dari segi struktur. Lantai basement - dasar mempunyai loncatan bidang muka terhadap lantai 1 dan denah tipikal sampai lantai 12.

Informasi bangunan untuk peemodelan struktur sebagai berikut :

\begin{tabular}{|c|c|}
\hline & \\
\hline & Apartemen \\
\hline in & $47 \mathrm{~m}(12$ Lantai + Basement $)$ \\
\hline $\begin{array}{l}\text { Utama } \\
\text { ah }\end{array}$ & $\begin{array}{l}\text { Beton Bertulang } \\
\text { Lunak }\end{array}$ \\
\hline
\end{tabular}

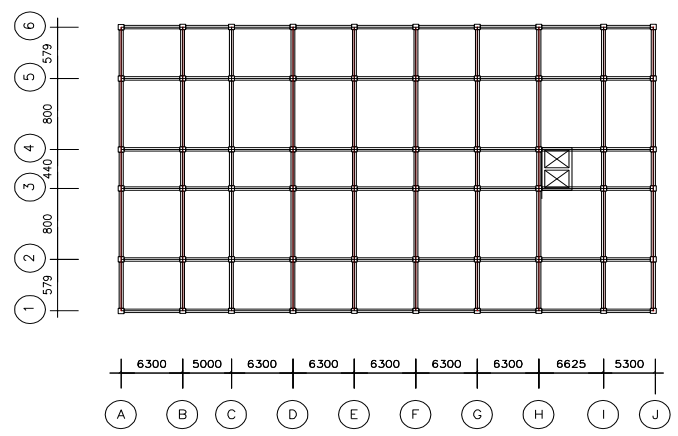

Gambar 2. Denah Lantai Basement dan Dasar

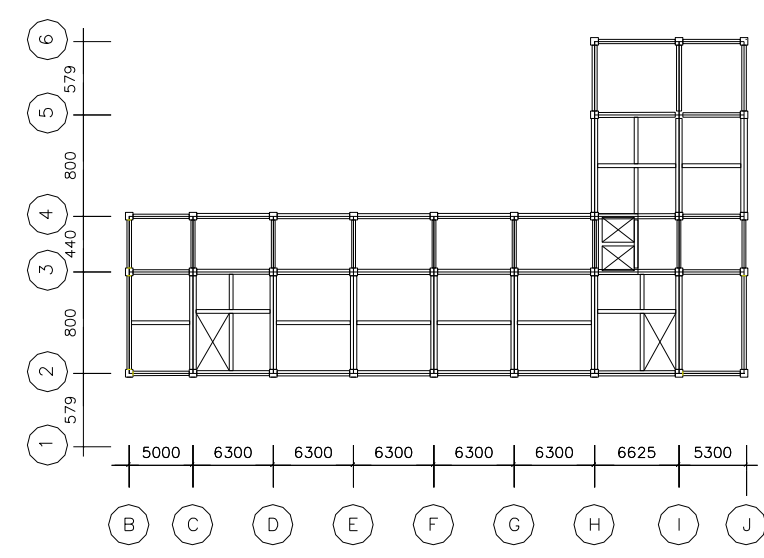

Gambar 3. Denah Lantai 1- 12

\section{B. Tahap Pemodelan Struktur}

Gedung dimodelkan menggunakan SAP2000 secara 3D. Sebelum dimodelkan, dihitung pembebanan berdasarkan SNI 03-1727-2013 [5] dan PPIUG1983[6], antara lain beban mati, hidup dan beban gempa (SNI 1726-2012).

\section{Tahap Analisis Struktur (Respon Spektra)}

Setelah gedung dimodelkan, kemudian di analisis dengan respon spektra dan dikontrol desain tersebut terhadap simpangan.

\section{Menghitung Kebutuhan Tulangan}

Hasil analisis dengan respon spektra kemudian dihitung kebutuhan tulangannya dengan hanya meninjau balok dan kolom pada setiap lantai (memanjang ujung dan tengah serta melintang ujung dan tengah. Kebutuhan tulangan dihitung menggunakan SAP2000 dan dikontrol dengan perhitungan manual sesuai SNI 03-2847-2013 [7]. dan perhitungan menggunakan buku literatur [8].

\section{E. Analisis Linier Time History}

Desain yang telah direncanakan dengan analisis respon spektra kemudian dievaluasi dengan analisis linier time history dengan menggunakan 3 (tiga) gempa dan diambil nilai terbesar.

\section{HASIL DAN PEMBAHASAN}

\section{A. Analisis Gempa dengan Respon Spektra}

1. Menetukan Kategori Desain Seismik 
Didapatkan kategori D.

2. Memilih Sistem dan Parameter Struktur

Dengan kriteria yang ada didapatkan nilai $\mathrm{R}=7$, dan $\mathrm{Cd}=5,5$.

3. Menentukan Periode Fundamental Struktur

Ketinggian struktur adalah $47 \mathrm{~m}$ dan tipe struktur yang digunakan adalah sistem ganda, jadi $\mathrm{Ta}=1,68$ detik

4. Menetukan Koefisien Respon Seismik

Didapatkan nilainya adalah Cs $=0,0816$

5. Menetukan Berat Seismik Struktur

Berdasarkan perhitungan didapatkan besarnya $\mathrm{W}$ dari penjumlahan total struktur adalah 126548,13 KN.

6. Menentukan Geser Dasar Seismik

Geser dasar seismik (V) yang diatur oleh SNI 1726-2012 dirumuskan sebagai berikut :

$\mathrm{V}=\mathrm{Cs} \mathrm{x} \mathrm{W}$

$\mathrm{V}=0,0816 \times 126548,13=14462,64 \mathrm{KN}$

\section{B. Kontrol Nilai Akhir Respon Spektrum}

Berdasarkan SNI 1726-2012, nilai akhir Vdinamik harus lebih besar sama dengan 85\% Vstatik. Maka persyaratan tersebut dapat dinyatakan sebagai berikut :

Vdinamik $\geq 0,85$ Vstatik.

Tabel 2.

Nilai Base Shear Dinamik

\begin{tabular}{ccc}
\hline OutputCase & GlobalFX & GlobalFY \\
\hline Text & KN & KN \\
RSPX & 11621,343 & 8383,669 \\
RSPY & 8272,696 & 12038,64 \\
\hline \hline
\end{tabular}

Nilai geser dasar yang diambil dari hasil analisis SAP2000 tersebut harus memenuhi persyaratan kontrol untuk nilai akhir respon spektrum. Langkah perhitungannya sebagai berikut :

$\underline{\operatorname{Arah} \mathrm{x}}$

$\mathrm{V}_{\text {dinamik }} \geq 0,85 \mathrm{~V}_{\text {statik }}$

$11621,34 \geq 0,85 \times 10330,459$

$11621,34 \geq 8780,891$ oke

Arah y

$\mathrm{V}_{\text {dinamik }} \geq 0,85 \mathrm{~V}_{\text {statik }}$

$12038,64 \geq 0,85 \times 10330,459$

$12038,64 \geq 8780,891$ oke

\section{Kontrol Nilai Partisipasi Massa}

Menurut SNI 1726 - 2012 Pasal bahwa partisipasi massa harus menghasilkan sekurangnya $90 \%$ respon total dari perhitungan repon dinamik. Dibawah ini adalah output partisipasi massa dari program SAP2000.

Dari tabel 3 menunjukan bahwa pada mode ke 15 sudah mencapak $90 \%$, sehingga sudah memenuhi persyaratan.

Tabel 3.

Nilai Base Shear Dinamik

\begin{tabular}{lrrrr}
\hline \hline StepType & StepNum & Period & SumUX & \multicolumn{1}{c}{ SumUY } \\
\hline Mode & 1 & 1,209 & 0,43 & 0,15 \\
Mode & 2 & 0,976 & 0,6 & 0,58 \\
Mode & 15 & 0,050 & $\mathbf{0 , 9 4}$ & $\mathbf{0 , 9 3}$ \\
\hline \hline
\end{tabular}

Kontrol Nilai Simpangan (drift)

Berdasarkan SNI 1726-2012 untuk kontrol drift dirumuskan sebagai berikut:

$$
\delta x=\frac{C_{d} \delta_{s e}}{I_{e}}
$$

Keterangan :

$C_{d}=$ faktor amplifikasi defleksi dalam Tabel 2.10 [1]

$\delta_{s e}=$ defleksi pada lokasi yang disyaratkan pada pasal ini yang ditentukan dengan analisis elastis

$I_{e}=$ faktor keutamaan gempa yang ditentukan sesuai dengan 4.1.2 [1]

$\Delta_{n}=0,020 h_{s x}=0,020 \times 3000=60 \mathrm{~mm}$

$\Delta_{n}=0,020 h_{s x}=0,020 \times 5000=100 \mathrm{~mm}$

Tabel 4.

Kontrol Simpangan Akibat Beban Gempa Arah-X

\begin{tabular}{|c|c|c|c|c|c|}
\hline \multirow{3}{*}{ Level } & \multirow{2}{*}{ hi } & \multicolumn{2}{|c|}{$\delta_{\varepsilon(v+1)-} \delta \varepsilon_{(v)}$} & \multicolumn{2}{|c|}{$\delta \mathrm{x}=(\operatorname{cd} . \delta \varepsilon) / \mathrm{Ie}$} \\
\hline & & $\mathrm{U} 1$ & $\mathrm{U} 2$ & U1 & U2 \\
\hline & $\mathrm{mm}$ & $\mathrm{mm}$ & $\mathrm{mm}$ & $\mathrm{mm}$ & $\mathrm{mm}$ \\
\hline Atap & 47 & 5,4 & 4,4 & 29,7 & 24,21 \\
\hline 12 & 44 & 5,7 & 4,6 & 31,3 & 25,57 \\
\hline 11 & 41 & 5,9 & 4,8 & 32,4 & 26,28 \\
\hline 10 & 38 & 6,0 & 4,9 & 33,2 & 26,81 \\
\hline 9 & 35 & 6,2 & 4,9 & 33,9 & 27,21 \\
\hline 8 & 32 & 6,2 & 5,0 & 34,2 & 27,30 \\
\hline 7 & 29 & 6,2 & 4,9 & 34,1 & 27,05 \\
\hline 6 & 26 & 6,1 & 4,8 & 33,5 & 26,44 \\
\hline 5 & 23 & 5,9 & 4,6 & 32,4 & 25,43 \\
\hline 4 & 20 & 5,6 & 4,4 & 30,8 & 23,96 \\
\hline 3 & 17 & 5,2 & 4,0 & 28,6 & 22,04 \\
\hline 2 & 14 & 4,3 & 3,5 & 23,5 & 19,38 \\
\hline 1 & 11 & 6,3 & 4,6 & 34,9 & 25,46 \\
\hline Dasar & 8 & 2,0 & 1,5 & 11,1 & 8,32 \\
\hline Basement & 3 & 0,0 & 0,0 & 0,0 & 0 \\
\hline
\end{tabular}

Tabel 5.

Kontrol Simpangan Akibat Beban Gempa Arah-Y

\begin{tabular}{cccccc}
\hline \hline \multirow{2}{*}{ Level } & \multirow{2}{*}{ hi } & \multicolumn{2}{c}{$\delta_{\varepsilon(\mathrm{v}+1)} \delta \varepsilon_{(\mathrm{v})}$} & \multicolumn{2}{c}{$\delta \mathrm{x}=(\mathrm{cd} . \delta \varepsilon) / \mathrm{Ie}$} \\
\cline { 2 - 6 } & & $\mathrm{U} 1$ & $\mathrm{U} 2$ & $\mathrm{U} 1$ & $\mathrm{U} 2$ \\
\cline { 2 - 6 } & $\mathrm{mm}$ & $\mathrm{mm}$ & $\mathrm{mm}$ & $\mathrm{mm}$ & $\mathrm{mm}$ \\
\hline Atap & 47 & 3,46 & 4,80 & 19 & 26,4 \\
12 & 44 & 3,65 & 5,09 & 20,1 & 28,0 \\
11 & 41 & 3,79 & 5,25 & 20,8 & 28,9 \\
10 & 38 & 3,90 & 5,37 & 21,4 & 29,5 \\
9 & 35 & 3,98 & 5,46 & 21,9 & 30,0 \\
8 & 32 & 4,03 & 5,49 & 22,1 & 30,2 \\
7 & 29 & 4,02 & 5,46 & 22,1 & 30,0 \\
6 & 26 & 3,96 & 5,35 & 21,8 & 29,4 \\
5 & 23 & 3,84 & 5,16 & 21,1 & 28,4 \\
4 & 20 & 3,66 & 4,89 & 20,1 & 26,9 \\
3 & 17 & 3,40 & 4,53 & 18,7 & 24,9
\end{tabular}




\begin{tabular}{cccccc}
2 & 14 & 2,88 & 4,01 & 15,9 & 22,1 \\
1 & 11 & 4,12 & 5,39 & 22,7 & 29,7 \\
Dasar & 8 & 1,32 & 1,87 & 7,26 & 10,3 \\
Basement & 3 & 0,00 & 0,00 & 0 & 0,0 \\
\hline \hline
\end{tabular}

\section{Kontrol Sistem Ganda (Dual System)}

Kemampuan dari dinding geser dan rangka gedung dalam memikul beban lateral akibat gempa dapat dilihat pada tabel 6 .

Tabel 6.

Kontrol Sistem Struktur

\begin{tabular}{|c|c|c|c|c|c|c|c|}
\hline Kombinasi & \multicolumn{2}{|c|}{ SW } & \multicolumn{2}{|c|}{ Rangka } & \multicolumn{2}{|c|}{ SW } & Rangka \\
\hline 0,9DL+1RSPX & 10507,63 & 9631,37 & 9708,18 & 3281,34 & 51,98 & \begin{tabular}{|l|}
74,59 \\
\end{tabular} & \begin{tabular}{|l|l|}
48,02 & 25,41 \\
\end{tabular} \\
\hline $0,9 \mathrm{DL}+1 \mathrm{RSPY}$ & 7982,27 & 11502,41 & 7693,89 & 4075,92 & 50,92 & 73,8 & \begin{tabular}{l|l}
49,08 & 26,16 \\
\end{tabular} \\
\hline 1,2DL+1LL+1RSPX & 10477,87 & 9684,17 & 10344,31 & 3255,38 & 50,32 & 74,84 & \begin{tabular}{|l|l|}
49,68 & 25,16 \\
\end{tabular} \\
\hline 1,2DL+1LL+1RSPY & 7924,13 & 11615,21 & 7163,29 & 4065,06 & 52,52 & 74,08 & 47,4 \\
\hline
\end{tabular}

Dari tabel 6 dapat dilihat bahwa presentase rangka lebih besar dari $25 \%$, sehingga konfigurasi struktur gedung ini termasuk kategori sistem ganda (dual system).

\section{E. Pendetailan Tulangan}

1. Balok

Pendetailan balok dihitung dengan meninjau arah memanjang dan melintang disetiap lantainya. Adapun tipe pendetailan tulangan pada balok dapat dilihat pada tabel 7 dan 8 , gambar 4 dan gambar 5. Untuk semua tipe balok dapat dilihat pada naskah penelitian.

Tabel 7.

Rekapitulasi Tulangan Balok [9]

\begin{tabular}{cccc}
\hline \multicolumn{4}{c}{ Rekapitulasi Tulangan Balok [9] } \\
\cline { 2 - 4 } Kode Balok & \multicolumn{3}{c}{ Tulangan } \\
\cline { 2 - 4 } & Tump & Lap & Tump \\
\hline \multirow{2}{*}{ B2MU1 } & 3D19 & 2D19 & 3D19 \\
& 2D19 & 2D19 & 2D19 \\
\hline \multirow{2}{*}{ Kode Balok } & \multicolumn{3}{c}{ Tulangan } \\
\cline { 2 - 4 } & Tump & Lap & Tump \\
\hline \multirow{2}{*}{ B1LT1 } & 9D19 & 5D19 & 9D19 \\
& 5D19 & 5D19 & 5D19 \\
\hline \hline
\end{tabular}

Tabel 8.

$\underline{\text { Rekapitulasi Penulangan Geser Memanjang Ujung [9] }}$

\begin{tabular}{ccc}
\hline Lantai & B2MU1 & B4MU1 \\
\hline Dasar & $2 \mathrm{D} 10-100 / 150$ & $2 \mathrm{D} 10-100 / 150$ \\
\hline \hline
\end{tabular}

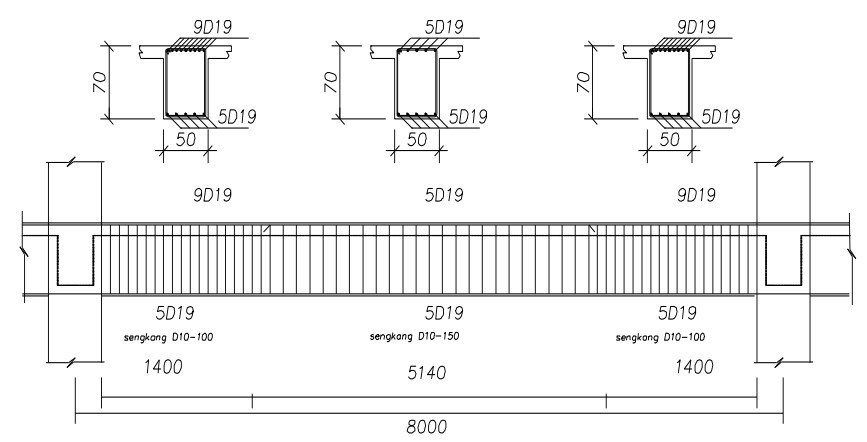

Gambar 4. Balok B1LT1

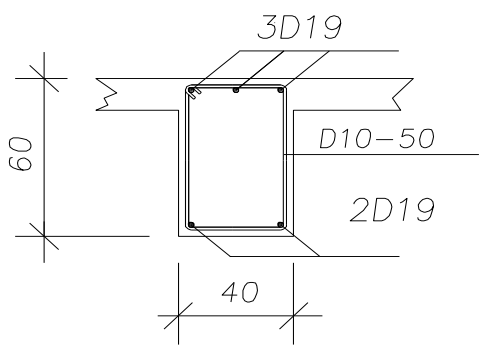

Gambar 5. Penampang B2MU1

Contoh penulangan balok terdapat pada tabel 7 dan 8 selebihnya terdapat naskah penelitian.

\section{Kolom}

Pendetailan kolom dihitung dengan meninjau arah memanjang dan melintang disetiap lantainya. Adapun tipe pendetailan tulangan pada kolom dapat dilihat pada tabel 9, gambar 6 dan gambar 7. Untuk semua tipe kolom dapat dilihat pada naskah penelitian.

Tabel 9.

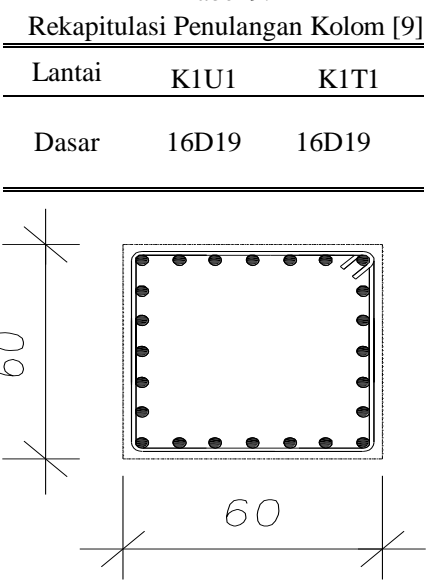

Gambar 6. K1U1

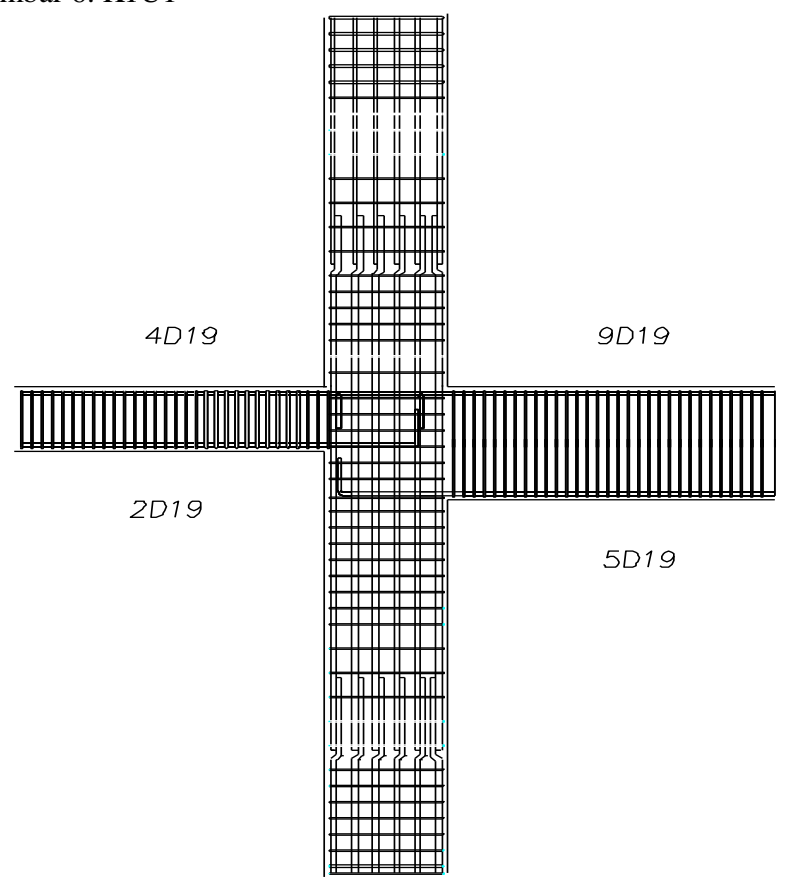

Gambar 7 Beam Column Joint Lantai 1-2 


\section{F. Analisis Linier Time History}

Untuk memasukkan nilai ground motion kedalam analisis time histoy, diperlukan hasil proses tambahan karena setiap gempa berbeda letak dan besarnya, sehingga dibutuhkan penskalaan. Dengan penskalaan, gempa dapat dicocokkan dengan spektrum di wilayah yang ditinjau. Proses penskalaan dilakukan pada rentang

$\mathrm{T}=1,209 \mathrm{~s}$ ( $\mathrm{T}$ Bangunan Hasil Analisis SAP)

$0,2 \mathrm{~T}=0,2 \times 1,209=0,2418 \mathrm{~s}$

$1,5 \mathrm{~T}=1,5 \times 1,209=1,8135 \mathrm{~s}$

Tahap-tahap penskalaan sebagai berikut :

1. Mengubah data ground motion menjadi spektrum dengan software SeismoSignal karena penskalaan ditinjau dalam bentuk spektrum.

2. Ambil data data pseudo-acceleration dari software tersebut.

3. Hitung faktor skala dengan rumus dari Kalkan dan Chopra dan diperoleh scale factor

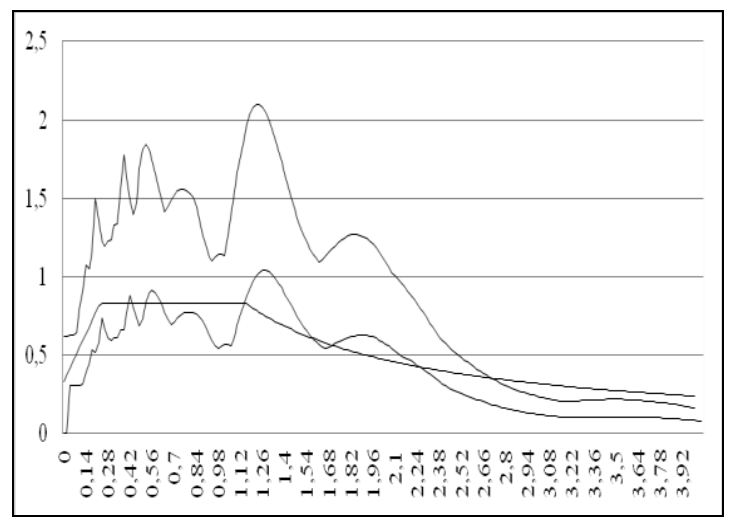

Gambar 8 Batasan Penskalaan Gempa Rencana Kobe - X

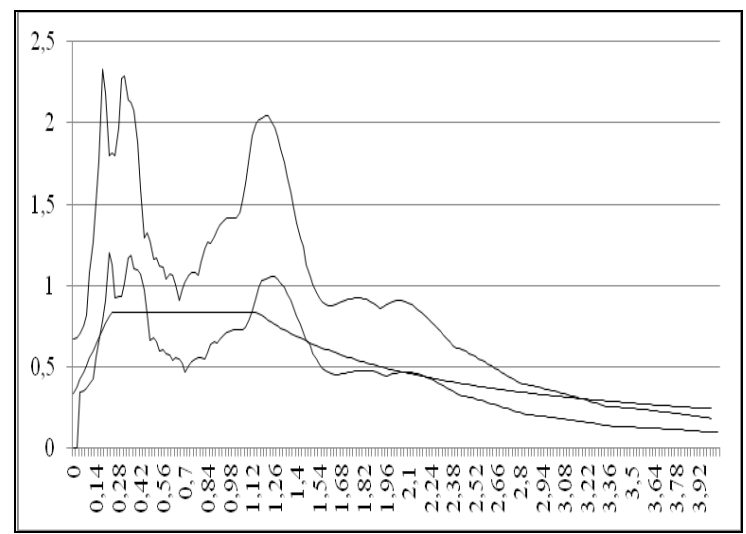

Gambar 9 Batasan Penskalaan Gempa Rencana Kobe - Y

\section{a . Base Shear}

Tabel 10.

Perbandingan Nilai Base Shear

\begin{tabular}{cccc}
\hline \hline Respon Spektra & Kobe & Imperial Valley & Tabas \\
\hline $11621,343 \mathrm{KN}$ & $10580 \mathrm{KN}$ & $2691 \mathrm{KN}$ & $9879 \mathrm{KN}$ \\
$12038,64 \mathrm{KN}$ & $9591 \mathrm{KN}$ & $1115 \mathrm{KN}$ & $9440 \mathrm{KN}$ \\
\hline \hline
\end{tabular}

Diperoleh nilai base shear maksimum pada gempa setiap arah gempa yang ditinjau. Hasil base shear kobe arah $\mathrm{x}$ sebesar $1,058 \times 10^{4} \mathrm{KN}$ pada detik ke 6,5; kobe arah y sebesar $9,591 \times 10^{3} \mathrm{KN}$ pada detik ke 6,1; imperial valley arah $\mathrm{x}$ sebesar 2,691 x $10^{3} \mathrm{KN}$ pada detik ke 3,385; imperial valley y sebesar $1,115 \times 10^{3} \mathrm{KN}$ pada detik ke 10,02 ; tabas $\mathrm{x}$ sebesar $9,879 \times 10^{3} \mathrm{KN}$ pada detik ke 20,326 dan tabas y sebesar 9,44 x $10^{3} \mathrm{KN}$ pada detik ke 20,06.

Nilai base shear yang terbesar dari kedua analisis yaitu nilai base shear dengan analisis respon spektra. Dari gambar 10, dapat diketahui bahwa nilai base shear gempa Imperial Valley mengalami perubahan yang drastis. Hal ini bisa terjadi seperti pada beberapa studi yang membahas tentang analisis linier time history. Nilai base shear pada beberapa gempa yang ditinjau mengalami perubahan yang signifikan [10].

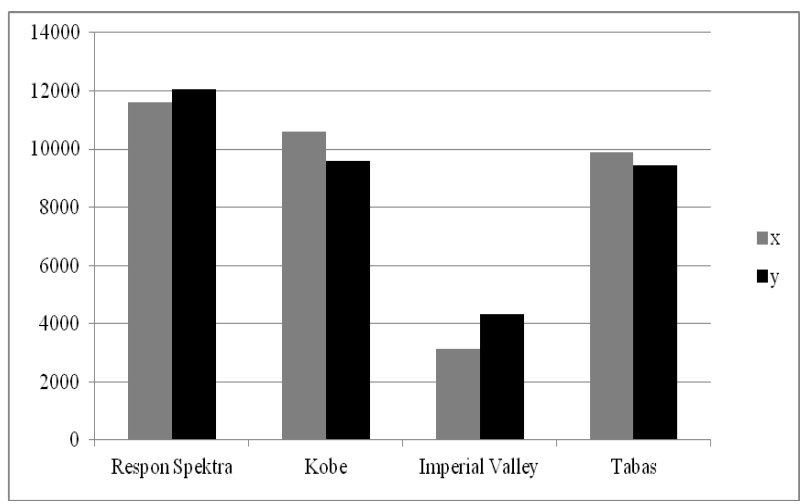

Gambar 10 Perbandingan Simpangan Maksimum Respon Spektra dan Linier Time History Gempa Arah -X

\section{b. Simpangan}

Perbandingan simpangan pada analisis time history diambil simpangan maksimum dari ketiga gempa arah $\mathrm{x}$ dan $\mathrm{y}$. Pada gambar 11 dan 12 terlihat bahwa hasil simpangan desain gedung dengan respon spektra aman terhadap simpangan ijin, kemudian dievaluasi dengan analisis linier time history masih dalam kategori aman tapi pada simpangan arah - x, gempa imperial valley melebihi simpangan respon spektra dan arah y di beberapa lantai melebihi respon spektra. Data simpangan menunjukkan bahwa gempa imperial valley menyebabkan simpangan terbesar dari ketiga gempa yang ditinjau.

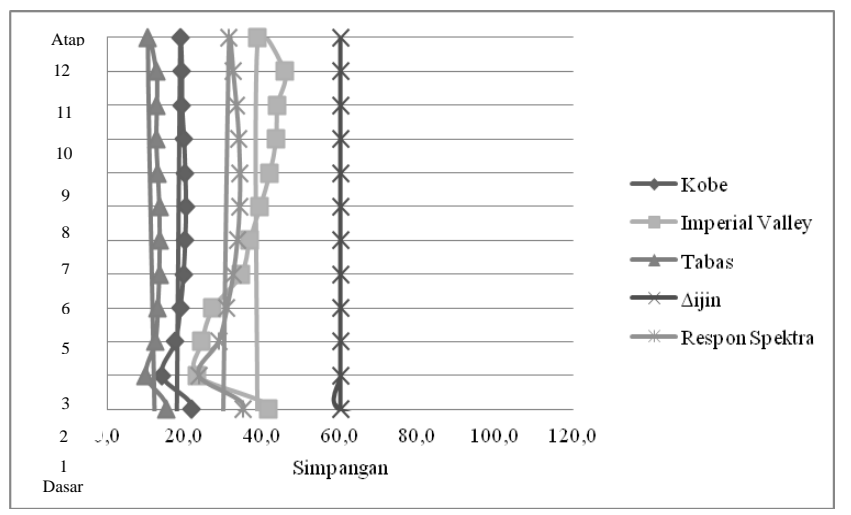

Gambar 11 Perbandingan Simpangan Maksimum Respon Spektra dan Linier Time History Gempa Arah -X 


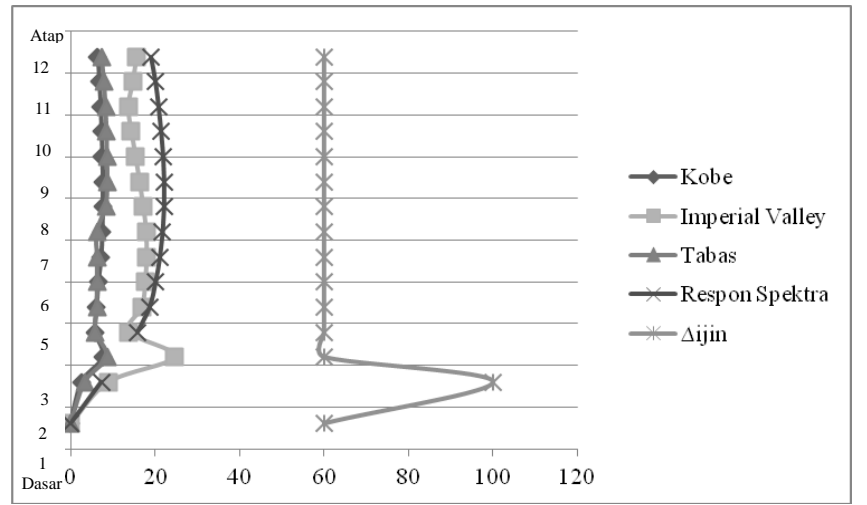

Gambar 12 Perbandingan Simpangan Maksimum Respon Spektra dan Linier Time History Gempa Arah $-\mathrm{Y}$

\section{c. Velocity}

Nilai velocity maksimum pada gempa setiap arah gempa yang ditinjau. Hasil velocity maksimum kobe arah $\mathrm{x}$ sebesar $2,556 \times 10^{2} \mathrm{~mm} / \mathrm{s}$ pada detik ke 8,1 ; velocity maksimum imperial valley arah $\mathrm{x}$ sebesar $3,158 \times 10^{1} \mathrm{~mm} / \mathrm{s}$ pada detik ke 7,99; velocity maksimum tabas arah $\mathrm{x}$ sebesar 7,446 $\times 10^{2}$ $\mathrm{mm} / \mathrm{s}$ pada detik ke 23,68; velocity maksimum kobe arah y sebesar $9,499 \times 10^{1} \mathrm{~mm} / \mathrm{s}$ pada detik ke 7,36 ; velocity maksimum imperial valley arah y sebesar $2,335 \times 10^{1} \mathrm{~mm} / \mathrm{s}$ pada detik ke 5,945; velocity maksimum tabas arah y sebesar $5,901 \times 10^{2} \mathrm{~mm} / \mathrm{s}$ pada detik ke 22,60.

\section{d. Acceleration}

Nilai acceleration maksimum pada gempa setiap arah gempa yang ditinjau. Hasil acceleration kobe arah x sebesar $1,507 \times 10^{2} \mathrm{~mm} / \mathrm{s}^{2}$ pada detik ke 7,76; acceleration maksimum imperil valley arah x $3,708 \times 10^{2} \mathrm{~mm} / \mathrm{s}^{2}$ pada detik ke 3,54; acceleration maksimum tabas arah $\mathrm{x}$ sebesar 7,184 $\mathrm{x} 10^{3}$ $\mathrm{mm} / \mathrm{s}^{2}$ pada detik ke 23,14; acceleration maksimum kobe arah y sebesar $6,76 \times 10^{2} \mathrm{~mm} / \mathrm{s}^{2}$ pada detik ke 7,21; acceleration maksimum imperial valley arah y $2,273 \times 10^{2} \mathrm{~mm} / \mathrm{s}^{2}$ pada detik ke 5,795; acceleration maksimum tabas arah y sebesar 5,458 x $10^{3} \mathrm{~mm} / \mathrm{s}^{2}$ pada detik ke 23,18 .

\section{KESIMPULAN DAN SARAN}

\section{A. Kesimpulan}

Berdasarkan pembahasan sebelumnya, dapat disimpulkan sebagai berikut :

1. Hasil desain struktur berupa gambar, terdapat pada naskah penelitian [9].

2. Base shear terbesar dari linier time history yaitu gempa Kobe dengan hasil sebesar $10580 \mathrm{KN}$ arah x dan $9691 \mathrm{KN}$ arah y. Nilai base shear respon spektra lebih besar dibandingkan analisis linier time history yaitu sebesar $11621,343 \mathrm{KN}$ arah x dan 12038,64 KN arah y. Presentase penurunan nilai base shear dari 3 (tiga) gempa dengan analisis linier time history terhadap respon spektra yaitu sebesar 4,69 \% Kobe - x ; 11,32\% Kobe -y; 62,4\% Imperial Valley - $\mathrm{x} ; 83,046 \%$ Imperial Valley - y; 8,1\% Tabas - $\mathrm{x}$ dan $12,1 \%$ Tabas - $\mathrm{y}$.

3. Hasil simpangan desain gedung dengan respon spektra aman terhadap simpangan ijin, kemudian dievaluasi dengan analisis linier time history masih dalam kategori aman tapi pada simpangan arah - x, gempa imperial valley melebihi simpangan respon spektra dan arah y di beberapa lantai melebihi respon spektra. Data simpangan menunjukkan bahwa gempa imperial valley menyebabkan simpangan terbesar dari ketiga gempa yang ditinjau. Simpangan yang besar terjadi akibat base shear yang kecil, dapat dilihat pada hasil base shear dari gempa Imprial Valley. Semakin besar base shear maka struktur bangunan semakin kaku, jadi niali base shear yang kecil mengakibatkan makin besar nilai simpangan.

\section{B. Saran}

Berdasarkan pembahasan sebelumnya, agar studi lebih luas dan detail penulis menyarankan beberapa poin sebagai berikut :

1. Menggunakan rekaman gempa (ground motion) sebanyak 7 (tujuh) atau lebih agar mendapatkan hasil yang lebih teliti dan dapat disimpulkan analisis desain yang lebih menguntungkan.

2. Menggunakan analisis gempa non linier time history untuk mendapatkan perilaku struktur dan dibandingkan dengan analisis linier.

\section{DAFTAR PUSTAKA}

[1] Nasional, B. S., 2012. Standar Ketahanan Gempa Untuk Struktur Bangunan Dan Lain. SNI 1726-2012 penyunt. s.1.:s.n.

[2] Pasific Earthquake Research Center, 2016. Pasific Earthquake Engineering Research Center. [Online] Available at: http://peer.berkeley.edu/ [Diakses 12 September 2016].

[3] Kalkan, Erol., dan Anil K Chopra. 2010. "Practical Guidelines to Select and Scale Earthquake Records fo Nonlinier Respone History Analysis of Structures". Open File Report U.S. Departement of the Interior and U.S. Geological Survey. USGS and Earthquake Engineering Research Institute.

[4] Villaverde, Roberto. 2009 "Fundamental Concepts of Earthquake Engineering". London : CRC Press.

[5] Nasional, B. S., 2013. Beban Minimum Untuk Perancangan Bangunan Gedung Dan Struktur Lain. SNI 1727 : 2013 penyunt. s.1.:s.n.

[6] Bangunan, D. P. M., 1983. Peraturan Pembebanan Indonesia Untuk Gedung 1983. Cetakan Kedua penyunt. Bandung: Yayasan Lembaga Penyelidikan Masalah Bangunan.

[7] Nasional, B. S., 2013. Persyaratan Beton Struktural Untuk Bangunan Gedung. SNI 2847:2013 ed. s.1.:s.n.

[8] Edward G Nawy, T. B. K., 2010. Beton Bertulang. Jilid 1 penyunt. Surabaya: ITS Press

[9] Dilla Ayu Laila Nurul Bayyinah, F., 2017. Studi Perbandingan Analisis Respon Spektra dan Time History untuk Desain Gedung, Surabaya: Institut Teknologi Sepuluh Nopember.

[10] Onur Merter, T. U., 2013. A Comparative Study on NonliniearStatic and Dynamic Analysis of RC Frame Structures. Journal of Civil Engineering and Science, September.Volume 2. 